\title{
Voices of the hungry: a qualitative measure of household food access and food insecurity in South Africa
}

\author{
Gamuchirai Chakona* (D) and Charlie M. Shackleton
}

\begin{abstract}
Background: South Africa is rated a food secure nation, but large numbers of households within the country have inadequate access to nutrient-rich diverse foods. The study sought to investigate households' physical and economic access and availability of food, in relation to local context which influences households' access to and ability to grow food which may affect the dietary quality. We sought to understand self-reported healthy diets, food insecurity from the perspective of people who experienced it, barriers to household food security and perceptions and feelings on food access as well as strategies households use to cope with food shortages and their perceptions on improving household food security.

Methods: Focus group discussions were conducted along a rural-urban continuum in three South African towns situated along an agro-ecological gradient. Participants were asked about their knowledge of healthy diets, factors influencing their food consumption, their perceptions regarding food insecurity, barriers to food security, coping strategies and solutions to improve access to nutrient-rich foods.

Results: A total of 91 people participated in 11 focus groups, with $76 \%$ females. The majority of participants aged between 31 and 50 years. Participants were knowledgeable about healthy diets but had limited access to it hence consumed monotonous diets. The perceptions provided insights into the pressing issues of inadequate access to food, food insecurity, coping strategies and ideas on improving food security. The majority of participants reported on experiencing food insecurity and female-headed households, unemployed and orphaned children were most vulnerable. Focus group participants highlighted the complexity of the food system in their communities which relies on own production, collecting from open spaces, donations and to a larger extent purchase, in the context of unemployment, low income, water and land shortages as well as theft.
\end{abstract}

Conclusion: The results provide a significant contribution from a needs assessment perspective from the communities, identify "hidden" constrains in household food access and provide effective future solutions for improving food security in the communities. Government should assist with capacity building, employment creation and providing resources (especially, land and water) for communities to practise agriculture which they all agreed can improve food security.

Keywords: Focus group discussions, Food access, Food insecurity, Agro-ecological gradient, Rural-urban continuum, Own production

*Correspondence: matarutseg@yahoo.com

Department of Environmental Science, Rhodes University,

Grahamstown 6140, South Africa 


\section{Background}

South Africa has one of the highest rates of income inequality in the world and has extremely high levels of absolute poverty [1]. While the country is rated as a food secure nation, large numbers of households within the country are food insecure with high prevalence of undernutrition, mainly due to high poverty and unemployment [1, 2]. Also, a decline in smallholder agriculture in South Africa [3, 4] has exacerbated the levels of food insecurity as the majority of the population accesses food via purchase. Due to increased urbanisation and the recent drought in southern Africa, household agriculture is becoming less significant as a primary food source yet food prices are rising in South Africa and the region [5, 6], hence increasing food insecurity of the poor. This has a negative impact on a large proportion of households already vulnerable to food insecurity, thereby increasing hunger and malnutrition in the country $[1,7,8]$.

Achieving food security requires that people have enough food for an active and healthy life at all times [9]. Access to enough food of diverse and good quality in a socially acceptable way is important. Food security as defined by the South African government is "physical, social and economic access to sufficient, safe and nutritious food by all South Africans at all times to meet their dietary and food preferences for an active and healthy life" [10]. Access to sufficient, safe and nutritious food is dependent largely on household and individual's socioeconomic status, and this exists when a household is able to secure food through purchasing, own production or from other sources such as food donations, transfers or grants and even collecting wild foods [11]. Local context (i.e. households along different agro-ecological potential areas and rural-urban continuum have different experiences in accessing food) also plays a role [11].

In South Africa, household food security is determined by household income to a large extent rather than by household food production [12-14]. Many South African households have abandoned farming because they regard it as a "fall back" activity which they only practise when it is convenient to them and necessary and some regard food production as a sign of extreme poverty [15]. However, own production has been proven to improve food security of poor households in many communities by reducing the dependence on purchased food [11, 16, 17]. Furthermore, in many South African communities, the collection of wild foods has been noted as an important strategy for households to access food [18-20]. Some urban households even grow indigenous or domesticated vegetables for consumption and selling any surplus to alleviate both food insecurity and poverty [21, 22]. Wild foods contribute to the food basket of many households and can make a significant contribution in alleviating household food insecurity in some settings [23-25].

Food security is a complex developmental issue which is costly and complicated to address as well as to measure, although a number of approaches have been used $[12,26]$. One approach to measuring household food security is achieved through the use of direct and indirect indicators to determine household food supply, food access and the outcomes of adequate food consumption [12, 27]. Household food supply mainly reflects on sources of food, for example, whether a household obtains food through own production, from the market, through collecting from open spaces or donations. Food access indicators provide information on food entitlement and socio-economic status of the household. Thus, they assume that households consume a variety of foods when they have the means [28]. Food access measurements are regarded as crucial in food security studies because they can be used to assess the nature of food insecurity in households and assess the severity and for monitoring interventions [29]. Food security outcomes mostly measure food consumption and the different effects of consumption which could be an individual's nutritional status and influencing factors. This can be measured directly through the use of qualitative methods to measure peoples' perception of food insecurity [e.g. food diaries, participatory observations along with in-depth interviews and focus group discussions (FGD)] or indirectly through use of quantitative survey methods (e.g. measurements of dietary diversity and nutritional assessments using anthropometric surveys) [30]. Wolfe and Frongillo [30] further emphasise the importance of including tools which can measure both access to food and perceptions of food insecurity when measuring household food security in developing countries.

In South Africa, most published work on food security has used household surveys and neglected to seek an understanding of the feelings and perceptions of the people involved and why they do what they do. No study has utilised peoples' voices for understanding perceptions of and experiences of household food insecurity. In many affected households, the experience of food insecurity involves social and psychological anxiety or stress which is associated with not having enough food [31]. Psychological stress due to lack of access to food may constrain households from practising their "normal" day-to-day activities which may cause further stress, modification of cooking or eating patterns as well as disturbances of households' food acquisition and management practices [31]. Hamelin et al. [32] and Chan et al. [33] also pointed out the importance of understanding food insecurity from the households' perspectives. Also, there is limited information on understanding perceptions of and 
experiences of household food insecurity in different agro-ecological zones as well as rural-urban continuum in South Africa. The study also considered agro-ecological zones (AEZs), which are geographical areas exhibiting similar climatic conditions that determine their ability to support rain-fed agriculture as influenced by latitude, elevation and temperature, as well as seasonality, rainfall amount and distribution during the growing season, and these have influence on household diets and food access [11]. The influence of the rural-urban gradient was examined to fully understand the different perceptions and experiences of households residing in rural, peri-urban and urban areas as the relationship between food production and food insecurity may differ between rural, peri-urban and urban system [11].

The aims of the study were to (1) investigate the "hidden" constraints in the measures of physical and economic access and availability of food, in relation to local context which influences access to and ability to grow food which may affect the dietary quality of households; (2) understand food insecurity from the perspective of people who experienced it; (3) understand the community perceptions about food security, food abundance in their area, farming, self-reported healthy diets and perceptions and feelings on how and where they access food; (4) determine what respondents perceived as food insecurity and the barriers to household food security; (5) examine whether communities had limited access to food and how this influenced their diets, dietary diversity and their choice of food; and (6) what strategies households used to cope with food shortages and their perceptions on improving their food security status. A number of hypotheses were posed:

1. Communities would have knowledge about healthy eating, but many households will not practise such due to a lack of resources to buy diverse foods.

2. Food will be abundant throughout the year, but some will face difficulties in accessing diverse foods due to high food prices and a lack of resources.

3. Communities would perceive diverse and interconnected factors to be causing food insecurity in their communities.

4. Poor households would cope with food insecurity using a number of different strategies irrespective of local context.

5. School feeding programmes and social grants would help in improving food security for poor households.

\section{Methods}

The study was carried out in three medium-sized towns in South Africa, namely Richards Bay, Dundee and Harrismith which are situated along an agro-ecological gradient [11]. Richards Bay is a coastal and relatively warm and wet town (approximately $970 \mathrm{~mm}$ rainfall per annum), while Harrismith is an inland and dry town (approximately $622 \mathrm{~mm}$ rainfall per annum) and Dundee being intermediate (inland and $683 \mathrm{~mm}$ rainfall per annum). The seasonality of the rainfall increases along this gradient, along with the severity of winter temperatures. The gradient therefore reflects one of declining suitability for rain-fed agriculture, from high in Richards Bay to low in Harrismith where rural farms mostly practise cattle ranching. Each study site consisted of the rural, peri-urban and urban complex, and data were collected along the rural-urban continuum. All interviews were conducted in the respondents' preferred language of isiZulu in Richards Bay and Dundee, and Sesotho in Harrismith or English and ethics approval was granted by the Rhodes University Ethical Standards Committee with Permit Number RU-HSD-14-08-0012.

\section{Focus group discussions (FGD)}

A focus group is a small group discussion of issues relevant to a topic and is frequently used to collect qualitative data [34]. Focus group discussions, like other qualitative research methods, can be used to develop an understanding of the meaning and experiences of peoples' lives from the point of view of those who experience it $[35,36]$. They have been used in food security studies to obtain information regarding food choices and diets within the context of lived experiences [33,37]. Thus, one can obtain information on the beliefs or feelings of individuals and why they act in the way they do.

In this study, 11 focus groups were conducted in October to November 2014; four in Richards Bay, four in Dundee and three in Harrismith. The focus groups were in mostly the rural and peri-urban sites, with only one urban focus group discussion (in Dundee) due to difficulties in getting participants in urban locations. Informed consent was obtained from each participant in the focus groups. Each focus group took between 45 and $60 \mathrm{~min}$, and in all focus groups there was an interpreter, translator and an assistant. The principal researcher led all the discussions. For each FGD, both the principal researcher and the assistant made notes of all the discussions and the responses that appeared most often in the group discussions. All questions which were asked in the FGDs were open-ended, and the core questions in each FGD included aspects on:

1. Household diets and why households ate the mentioned foods.

2. Knowledge about dietary diversity, perceived characteristics of a healthy diet and whether households were able to provide for a healthy diet. 
3. Sources of food and perceived time of the year when they have food in abundance or not.

4. Communities' attitudes towards own production and food purchasing.

5. Perceived factors influencing communities' and households' access to food.

6. What participants perceived as food secure, food insecure and the causes of food insecurity in their areas.

7. The coping strategies that are implemented by households to combat food shortages.

8. Suggestions on how to improve food security in their areas.

Male and female individuals from a wide range of age and socio-economic statuses were invited to participate in the FGDs by their community leaders. Groups were differentiated by selected socio-economic attributes because participants with similar characteristics become more comfortable with each other and can participate freely in the discussions. The FGDs were held in comfortable, peaceful and convenient settings. At the end of each session, all the notes were compiled because compiling the research data soon after the discussions helps in linking accurately the statements to anonymously coded individual identifiers in each group [33].

The geographical distributions, sample size, age and gender of all the participants are shown in Table 1. In order to recruit a random sample of focus group discussion participants, community leaders and village chiefs and village heads were contacted to help with organising the participants and determine venues and times for the focus groups. A total of 91 people participated in the focus group discussions, with about 6-11 attending per community. The age of the participants ranged from 19 to $>50$ years, and the FGDs were mostly represented by women and people aged from 31 years and above. Most people who attended the FGDs were from the rural areas with a few representatives from the peri-urban areas of which most had informal employment. Those who were formally employed, mostly males and those residing in urban areas chose not to attend the focus groups.

\section{Participatory transect walks}

A member was selected randomly from the focus group participants. Only women agreed to participate in doing transect walks. Researchers jointly walked along transects from the respective homes to places where households often purchase, produce or collect their food. Notes and photographs regarding food acquisition, food diversity and food abundance within the community were captured, we observed, asked questions and listened carefully to what the participants were saying. The participants were encouraged to comment on the features and issues along the path and point out whatever they deemed worth mentioning or important. Five transect walks with five women were achieved, two in both Richards Bay and Dundee and one in Harrismith. Such "walking interviews" help to provide insights into links between food systems, daily household routines and perceptions, and space that would otherwise probably go unnoticed in the research process.

Table 1 Total number, age and gender distributions of focus group discussion participants along the agro-ecological gradient

\begin{tabular}{|c|c|c|c|c|c|c|c|c|}
\hline \multirow[t]{2}{*}{ Town and location } & \multirow[t]{2}{*}{ Focus group } & \multirow[t]{2}{*}{$N$} & \multicolumn{2}{|c|}{ Gender } & \multicolumn{4}{|c|}{ Number per age group in years } \\
\hline & & & Male & Female & $<20$ & $20-30$ & $31-50$ & $>50$ \\
\hline \multicolumn{9}{|l|}{ Richards Bay } \\
\hline Rural & Khayalethemba & 11 & 4 & 7 & 1 & 2 & 5 & 3 \\
\hline Rural & KwaMbonambi & 9 & 0 & 9 & 0 & 1 & 8 & 0 \\
\hline Rural & KwaMonica & 7 & 2 & 5 & 0 & 2 & 5 & 0 \\
\hline Peri-urban & Esikhaleni & 8 & 0 & 8 & 0 & 0 & 8 & 0 \\
\hline \multicolumn{9}{|l|}{ Dundee } \\
\hline Rural & Tayside & 10 & 2 & 8 & 0 & 3 & 5 & 2 \\
\hline Rural & Clones & 8 & 2 & 6 & 0 & 1 & 5 & 2 \\
\hline Peri-urban & Sibongile & 7 & 4 & 3 & 0 & 2 & 4 & 1 \\
\hline Urban & Dundee urban & 6 & 0 & 6 & 1 & 3 & 2 & 0 \\
\hline \multicolumn{9}{|l|}{ Harrismith } \\
\hline Rural & Makgolokweng & 10 & 5 & 5 & 0 & 0 & 6 & 4 \\
\hline Peri-urban & Intabazwe & 8 & 3 & 5 & 1 & 2 & 4 & 1 \\
\hline \multirow[t]{2}{*}{ Peri-urban } & Tshiame B & 7 & 0 & 7 & 1 & 2 & 3 & 1 \\
\hline & Total & 91 & 22 & 69 & 4 & 18 & 55 & 14 \\
\hline
\end{tabular}




\section{Data analysis}

Data from all the FGDs and participatory transect walks were entered into Microsoft Word 13 and were edited. Researchers read the transcripts several times to understand the information. During data analysis, we used qualitative content analysis (QCA) which is a research method used to interpret textual data content by using a systematic classification process that involves coding to identify patterns or themes. Data were then analysed through coding [38] using NVivo software. We identified similarities between the codes and combined those that were connected and at the same time forming the significant themes and categories for the discussions. The transcripts were coded for type of food, sources of food, reasons for consuming a particular diet, food security, reasons for being food secure, causes of food insecurity, own production, attitudes towards farming, time of food abundance and food insecurity coping strategies. The coded FGD comments were arranged into categories within relevant themes. The five themes and categories that came out from this study are shown in Table 2.

\section{Results \\ Dietary diversity \\ Food type}

Participants listed all the foods that they always consume in their households. A variety of foods were mentioned in all communities, but most of the foods mentioned were starch (such as pap (stiff maize porridge), rice, potatoes, samp (crushed maize), bread and dumplings), along with meat and vegetables. The vegetables mentioned by almost all the groups were cabbage, onion and spinach. Chicken was the meat most mentioned, although all types of meat were being consumed in the communities. Traditional foods and wild vegetables were also mentioned in most of the groups except the urban one. Fruits were rarely mentioned.

Table 2 Themes and categories

\begin{tabular}{ll}
\hline Theme & Category \\
\hline Dietary diversity & $\begin{array}{l}\text { Type of food } \\
\text { Sources of food } \\
\text { Why a particular diet }\end{array}$ \\
Food abundance & Periods of food abundance and scarcity \\
Agricultural practices & Own production \\
Food security & Barriers to farming \\
& Food secure or not \\
& Causes of food insecurity \\
Coping strategies & Ways to improve food security \\
\hline
\end{tabular}

We eat cabbage, spinach, beans, carrots, beetroot, mealies, amadumbe (Colocasia esculenta), potatoes, sweet potatoes, rice, pap, samp, dumplings, bread, amahewu, fish, all types of meat, mbaqanga (mixture of beans and mealie meal), isijinga (mash of butternut and mealie meal), eggs, isipaklapakla (wild spinach) and imbuya spitsa/mholika, zaqathi (wild white carrot) and sometimes fruits like bananas, peaches, oranges, apples, figs, grapes. Clones

\section{Sources of food}

In all the focus groups, participants acquired their food in different ways. Four main methods were mentioned in most of the groups, namely own production, purchasing, collecting from open spaces and donations from the Department of Social Development, friends and family. Some participants also mentioned that they have enrolled for "work for food" programmes where they would work and get food parcels. Purchasing was the major means of accessing food for most participants in all towns.

We get all this food from different sources. We produce some of the food in our gardens e.g. vegetables like spinach, cabbage, potatoes, onions, beetroot, beans and maize. The greater part of the food we eat is from purchasing. Dundee urban

Most of the food eaten here is from the supermarkets. We always buy our food. Intabazwe

However, all focus groups in Richards Bay mentioned that they produce most of their vegetables and also collect wild vegetables which they consume. They mentioned that they only buy the food which they are not able to produce and a few get donations from the government (Figs. 1, 2, 3, 4).

We grow our food in our gardens and open spaces around our areas. We have fields in open spaces and we collect some vegetables like imbuya. We only buy the food that we do not produce and use almost on daily basis like rice, sugar, milk, cooking oil, mealie meal and meat. Esikhaleni

We grow vegetables like cabbage and we collect some vegetables which grow on their own from the wild like imfino isiZulu. We also buy the food we eat from the supermarkets in town, small markets around our neighbourhood and kiosks. Food like bread we can get from the tuckshops. Those people who are lazy and do not want to work are getting food parcels from the Department of Social Development. Khayalethemba 

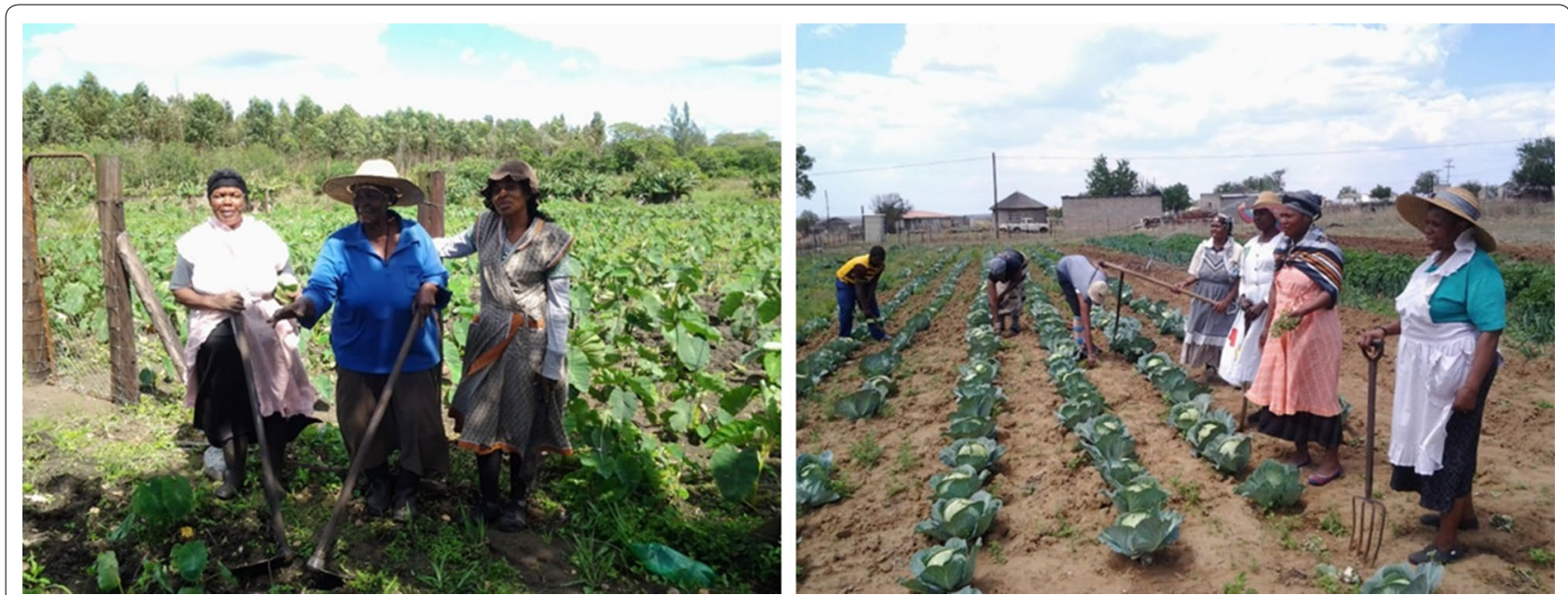

Fig. 1 Own production by community members in KwaMonica, Richards Bay (left) and Clones, Dundee (right)

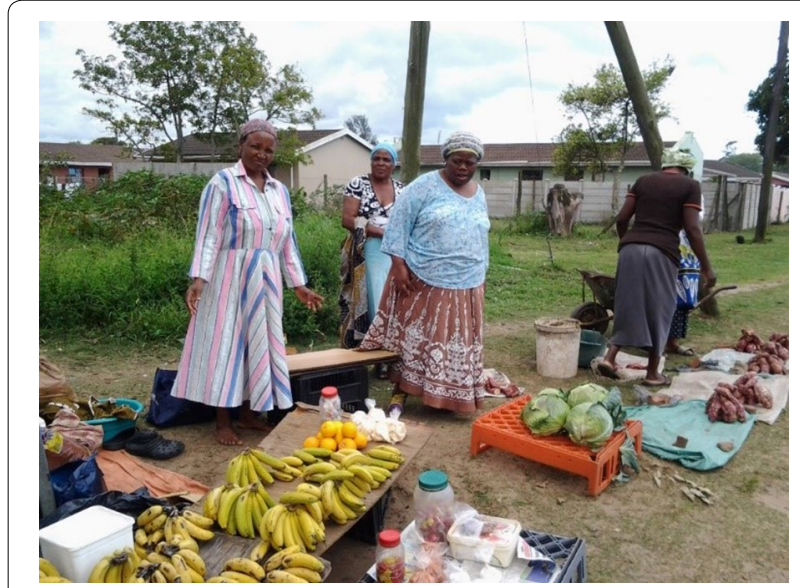

Fig. 2 Obtaining food from markets in Esikhaleni, Richards Bay

\section{Why a particular diet}

When asked whether they knew about a balanced diet, participants in all focus groups perceived that many people knew about healthy eating and getting enough nutrients for the body, although there were many factors which could force them into adopting a particular diet in their households.

We eat different types offood for healthy reasons. We get different types of nutrients from different types of food. We also eat different types of food so as to enjoy the meal and avoid being tired of the same type of meal always. Dundee urban

They diversify their diets to avoid getting tired of eating the same meal although they would sometimes consume different foods in the same food groups. Also, they
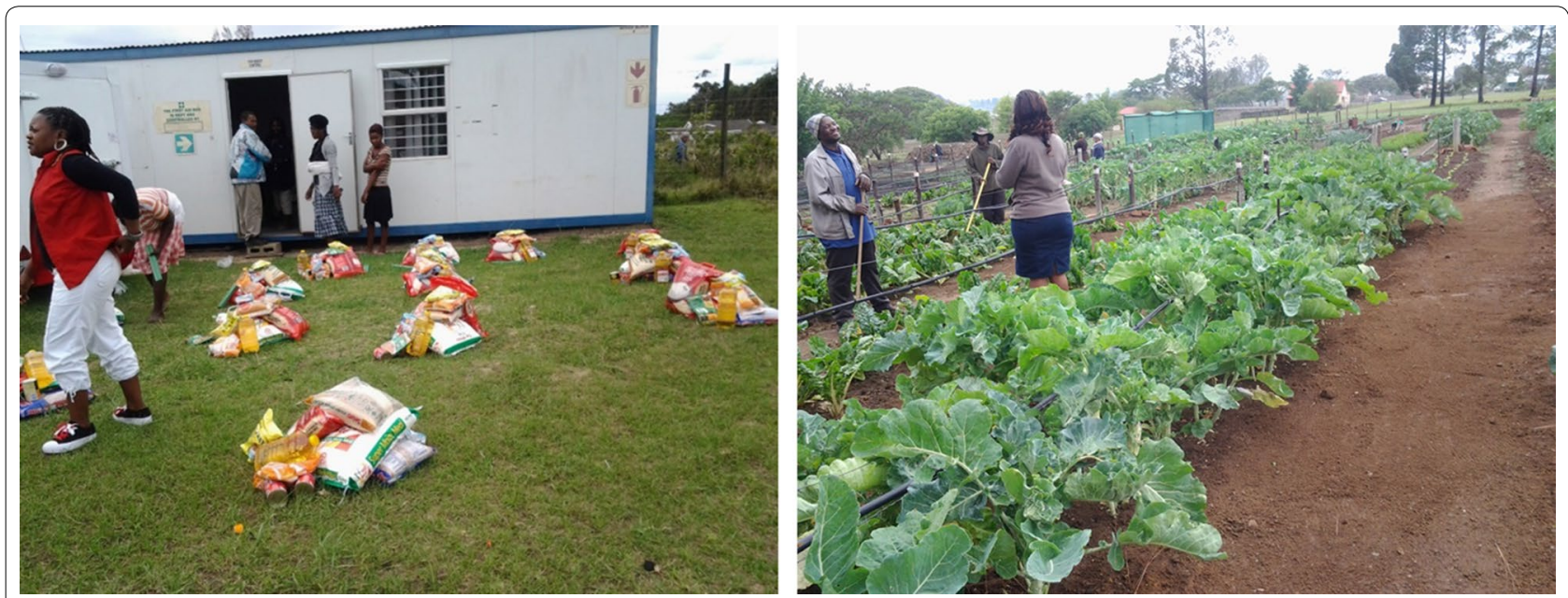

Fig. 3 Obtaining food from donations in Khayalethemba, Richards Bay (left) and work for food programmes for Sibongile residents in Dundee (right) 


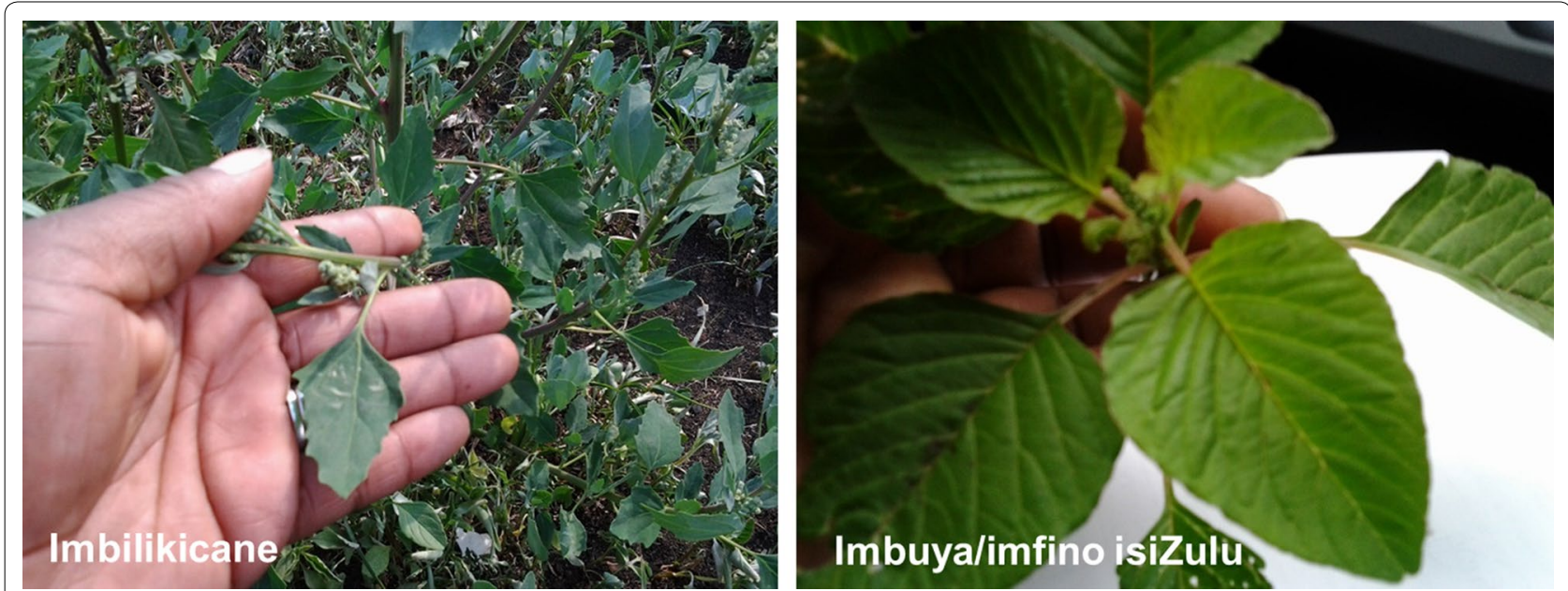

Fig. 4 Wild vegetables obtained from open spaces at Tayside in Dundee (left) and KwaMbonambi in Richards Bay (right)

consider the food which they produce as fresher, healthier and tastier than purchased food.

We eat different types of food for healthy reasons, for example, that is why we eat vegetables. Our food is healthier, fresh and tastes nice unlike shops' food which is unhealthy. At times we are forced by circumstances to eat the same type of food always. For example, we eat more of rice, pap and bread to fill our stomachs but we know it is not healthy since we will be missing some nutrients. You cannot just eat one thing over and over again because you get tired of it and your body will lack some nutrients. We eat beans because they are healthy and cheaper at the same time, but we do not enjoy eating them (beans). Also, they (beans) become costly because you cook for a long time and it charges electricity which is very expensive so sometimes we limit to cabbage. Some of us do not have husbands in our homes so we just eat whatever we get at that moment because we do not have money. KwaMonica

The participants also mentioned that the love for a particular food, preference, fulfilment of hunger, household income and just consuming the food present at the moment also influences their diet.

We normally eat so as to satisfy our stomachs and we do not consider food diversity. We only diversify due to preference and what is present. We do not consider a balanced diet, we just eat what is available. We like meat but if there is no money to buy it, we just eat pap and cabbage. Intabazwe

\section{Food abundance}

\section{Periods of food abundance and scarcity}

Time of food abundance was slightly different between towns as perceived by the focus group participants. Participants in different communities in the same town had mixed feelings about the time of the year they have more food, especially in Dundee. Some perceived that food is abundant in summer, others in winter and some said food was abundant all year-round in their communities.

We have more food in winter after we have harvested but also in summer when it rains we can get some food from the wild especially fruits and vegetables. Those with taps at their homes can produce vegetables throughout the year. Clones

In winter there is serious shortage of food but in summer it is better because of the rains so we can collect from the wild and there is food for the animals. Tayside

In Harrismith, focus group participants in all communities perceived that food was abundant in summer mainly due to low food prices. Some also perceived that food abundance can only be achieved when people have received their salaries or grants at the end of the months.

In summer, there is more food as people produce more. Food prices are low in summer because of increased supply from September to December. In winter production is low because of low rainfall therefore the food is imported from other places and food is very expensive. In summer, food prices are low so we are able to buy more food. Tshiame B 
There is enough food in summer after harvesting and because food prices are less than in winter. We also eat better after we receive grants but these grants are very little. Makgolokweng

In Richards Bay, all focus group participants agreed that they have enough food in abundance throughout the year, but winter was better than summer mostly due to more rains and pests in summer.

We have two seasons in this area, winter and summer. We get food in all seasons because it rains throughout the year therefore we produce food all year-round. However, we prefer winter because we harvest more during that season because there are less insects that affect plants in our gardens. In summer there is too much rain and insects which affect plant growth and produce. We harvest our plants all year-round but the big harvest is in winter. Khayalethemba

\section{Agricultural practices Own production}

In mostly Richards Bay and Dundee, some focus group participants were practising own production either in the form of keeping livestock or gardening. In Harrismith communities, this was rare. The animals which were kept were mostly cattle, goats and chickens. Cattle were mainly kept for meat, milk and ceremonies like paying lobola (bride-wealth) and performing some cultural rituals. Goats were kept for meat and also for cultural rituals. Chickens were kept for meat and selling, and rarely they would produce eggs. Communities also produced vegetables for food and selling. However, a number of communities were not happy with their level of production as they perceived they would do more if they had enough knowledge, resources, water supplies, land, enough pastures for the animals and also some help from the government.

We grow vegetables like spinach, cabbage and onions in our gardens for both our consumption and for selling. We keep chickens (both the traditional type and broilers), cattle, goats and sheep. We keep these animals mainly for food (meat and milk), to use in the fields and during some ceremonies like cattle to pay lobola and goats for our cultural rituals. We mostly keep broilers for selling but we do not sell our cattle. Meat production is affected by less pastures due to low rainfall. Also, there is an invasive plant (shanello yasendle) that is growing in the pasture areas and is affecting the growth of grass. This has affected the production of meat as there is not enough food for the domestic animals. We have very limited numbers of livestock because we do not have enough pastures to feed many. Therefore, we are discouraged from keeping a large herd of livestock. Also, there are some wild animals which come and eat our livestock. Clones

We produce enough vegetables to eat and a surplus for sell but some of the food and meat we buy from the markets. We fail to produce enough food because we lack the knowledge on how to go about proper farming. Agricultural officers just focus on distributing seeds to us but do not teach us on when, how and what to produce at a time. There are no practical lessons or follow ups on what they tell us. Our land is fertile, we put cow manure in the fields and we have good climate but we do not have enough knowledge to practice proper farming. Sometimes we grow enough and people from town come and buy. Some promise to come back and buy but they do not come so our products end up rotting. Our produce is wasted if we fail to get market especially cabbage. We need machines to use in preserving or drying our vegetables. We do not know how we can go about it and we are failing to get help from agricultural organisations. If we are given proper knowledge and progressive lessons with agricultural extension officers on how to farm, we believe we can improve our production. We also keep cattle, goats mainly for food (meat and milk). We also keep chickens for meat and we sell to get some money but we do not sell or slaughter our cattle always because they are very few so we normally use for ceremonies. Although we get meat from our livestock, we feel we can produce better quantities and quality if we get proper knowledge since we are not educated. Khayalethemba

We keep chickens mostly the traditional type for meat, our level of food production is limited by a number of things which are theft, water shortages, land is not enough, and we lack resources and knowledge to practice proper agriculture. Makgolokweng

\section{Perceived barriers to farming or gardening}

Focus group participants in almost all communities perceived that there are certain factors that hindered them from fully engaging in farming and many households had difficulties in practising own production. The perceived barriers to own production were related to lack of income and resources due to high levels of unemployment, lack of enough land, water shortages, theft, limited knowledge, insufficient government support, laziness and some form of individual lifestyle as some perceived 
farming or gardening a sign of living in poverty. However, participants in Richards Bay mentioned lack of knowledge, laziness and theft, as well as failure to get a market, as the major impediments to own production.

We have problems of animal theft in our communities so we do not keep much livestock. We get discouraged sometimes because we fail to get market for our produce and it ends up rotting and wasting away. We do not have the means to preserve our farm produce. We used to produce enough food to eat and a surplus for sell but now our land has been affected by Richards Bay minerals (RBM). RBM has affected our homes, land and water but they are not compensating us. Because of them we no longer have enough even the fruit trees we used to have in the open spaces like guava have dried. RBM have grown trees that are sucking water from the soil and these trees are making the soil to lose its fertility thereby affecting our crops. Before the mine was established, we used to have enough food as we were growing our own food and even getting fruits and imfino from the forests. However, there are community projects which we do where we work together, share ideas on how we can get better production but some community members do not cooperate because they are lazy and they feel that working in the fields is for poor people. KwaMbonambi

Farming in our area is not viable because we have limited land, we do not have farming equipment, seeds and fertilisers. We do not have money to buy these because most of us are unemployed. Water shortage is also a big issue in our area which is causing us not to produce more food. We can't make gardens flourish because the water we are using on daily basis is being supplied to us by trucks and we cannot run gardens through such water. The water supply is also not efficient and at times we go beyond a month without supply so our life becomes very difficult. Also, some people are lazy and do not want to work in the gardens. They think it is something that is done by the poorest. Because not everyone will be having gardens in the community, some of the food is stolen and this is discouraging most people because it's a waste. It is also difficult to keep so many domestic animals because of thieves in this area. We are willing to work with our hands to produce our own food but we have limited land and farming equipment. We desire to produce chickens (broilers) but there is a lot of criminal activities. It is difficult to produce because there are so many thieves in the area who can come and take the chickens when they are ready for sale. Makgolokweng
We have no enough land to make the gardens and fence to protect our gardens from animals although some are just lazy. Water is another big problem that hinders us from doing our own production. There is shortage of water and tap water is not reliable, most of the time we don't have water and this is a dry place with very limited rains. Often, the rains come too late for production of crops like maize. We cannot afford to buy fertilisers for our crops and we also do not have pest control measures for our crops and this affects production. Many lack agricultural knowledge but we feel we can produce better if we have the knowledge, enough land, water and income. Those are the main issues that are causing us not to do farming. Also, if we are helped with fencing our gardens so that no animals can eat our vegetables. Tayside

\section{Food security \\ Food secure or not}

Focus group participants in most communities perceived that they were food insecure although some expressed mixed feelings about some households in the communities being food secure and others experiencing food insecurity. Some participants, especially in Richards Bay, mentioned that they were food secure although some, mostly female-headed households were food insecure. In the other towns, most participants said they were food insecure and the government was just ignoring them.

Some families are getting all the food they need and they are food secure. Most of us are not employed and we do not have husbands to take care of us and the children, so we are not getting enough food. KwaMonica

Some households are food secure but food is not enough for the majority of the households. People are hungry and there is no food that they are getting from the government. Dundee urban

Not at all, we are very hungry people and we are suffering. Sibongile

No. The food is not enough in many homes, we are hungry. Intabazwe

\section{Causes of food insecurity}

Focus group participants in all communities of Dundee and Harrismith perceived that many households were facing difficulties in obtaining enough food for the whole family every month. They perceived that the causes of 
food insecurity in their communities were mostly related to unemployment, lack of land, unreliable rains and water shortages, high food prices, lack of income, insufficient support from the government and, to a lesser extent, laziness. Some participants from rural communities mentioned lack of land as a contributor to food insecurity, but this was not accepted by all participants because some mentioned that rural households have land, which, although not large, could at least be suitable for home gardens. The families that are most vulnerable to food insecurity are those that are female-headed with the burden of taking care of children and grandchildren and those with no source of income because the bread winner is unemployed. However, in Richards Bay participants perceived that many households who are suffering from food insecurity are lazy, although they also acknowledged that the unemployed, female-headed households and orphans are at great risk.

There are community projects which we do where we work together, share ideas on how we can get better production but some community members do not cooperate because they are lazy so they end up resorting to begging and handouts/food parcels from the Department of Social Development. These won't last for the whole month so they end up suffering from hunger and they keep on blaming the government and RBM, instead of working hard to get food. Those who do not want to work with their hands find themselves hungry and start begging for food or steal from our fields. Households with non-employed members struggle to get food and some are below the receiving age for elderly grant. Most are not getting the child support grant and they are carrying the burden of feeding and educating the orphaned children and their grandchildren. There are no food donations to cater for the orphaned children who are hungry. Female-headed households and orphans are suffering. KwaMbonambi

We are hungry because we do not have money to buy enough food and we do not have land to produce our own food. We are not employed so we don't have enough money to buy food. We don't have jobs, we don't have money and we do not have food. The other problem is electricity rates are very high and they are taking a huge chunk of our income which is the grant. We do not cook beans because it uses more electricity. The grant is not enough for everything like buying food, paying electricity bills and school fees. If we do not get the grant then there is a big problem and we go hungry even more since the money is not enough. There are no NGO's (Non-Governmental
Organisations) that are giving us support and Social Development people promised to come and provide food for us but they did not come. We are living in poverty and no one is helping us. We are very poor because most of us are not employed and this is striking hard on us. Sibongile

Many households are run by widows and single mothers and food shortages are higher in femaleheaded households. Some do not want to make gardens due to lack of resources but some it is just out of laziness especially the youth, they think it is for us old people. The area is dry and there are communal taps which provide water to everyone and some individuals have managed to draw water to their homes. Some have failed because of financial problems. The land is fertile but it is dry. Also, unemployment is on the rise. Clones

Food availability is not a problem at all, the problem is money. We are not employed, we don't have jobs and some are not getting grants from the government. Food is very expensive especially in winter because production is low because of low rainfall therefore the food is imported from other places. Food is available at the markets but if you do not have the money to buy you won't get it. Food is very expensive in these shops and the quantities are too little. The quantities in their packaging do not match the price and because we are not employed we have financial constraints and are not able to buy more. There is efficient transport system to take us to town where we can buy food at reasonable prices but these taxis are also very expensive. We do not have money because we are not working, we are struggling to make ends meet. For most households, food is not enough because we have to buy everything from the markets and it is very expensive. It is better if we get directly from the farmers because the prices are low. We therefore buy less and cheaper food which we do not want to avoid hunger. We are hungry because we cannot farm because we do not have the land, we do not have water and there is no food that we are getting from the government. If there are no rains, there is no food. Department of Social Development has promised to give us food parcels for children who do not receive child grants but the food parcels never came. The grant is too little, it won't last us for days because the money is too little to buy food for the month. Unemployment is the main problem, we are struggling to make ends meet. Makgolokweng 


\section{Ways to improve food security}

Participants in all communities had strong feelings that food security in their communities can be improved through working hard, being engaged in community projects and being formally employed. Although the projects can easily be implemented by the community members, some felt that they need financial support from the government as well as jobs. Participants in Dundee and Harrismith perceived that there is need for support in providing water and fencing for gardens as well as strategies to boost their knowledge on agriculture through community engagement programmes. They believe that engaging in agriculture, receiving food parcels and social grants can improve food security in their communities.

Those who work hard and families with employed bread winners are having enough food to feed their families and also to sell. Though we are not formally employed we grow some of our food and we get money through selling our produce then buy what we do not have. We have never experienced hunger before like what we hear from other places. We have enough food because we work hard. If you work hard you will have enough to put on the table. There are community projects which we do where we work together, share ideas on how we can get better production and the community members who are cooperating are getting food for their families from these project gardens. Also, if we are helped with fencing our gardens so that no animals can eat our vegetables. Khayalethemba
Some households are producing enough food for their families and these have water and land. Some homes have enough especially those homes with people who are formally employed. Therefore, employment, availability of land and water can improve food security in our communities. Clones

The families who work hard are food secure because they get the food to eat. Some families are getting food vouchers from social welfare, food parcels from NGOs and some are getting social grants. This is helping to fight against hunger. Dundee urban

Employment is the key to having enough food in many households. The homes that have enough food are those with people who are formally employed. If we also get jobs, this will improve our situation. Tshiame

\section{Coping strategies}

Although families in the study sites may experience food shortages at different levels, the coping strategies were similar across all communities. In all communities, the participants mentioned many strategies which they use to cope with food shortages (Table 3). In all communities, participants have agreed that the strategies in Table 3 have helped them to deal and manage food insecurity, although long-term measures that can sustain families should be implemented.

\section{Table 3 Strategies and practices implemented by families to cope with food insecurity}

\begin{tabular}{|c|c|}
\hline Strategy & Practice \\
\hline \multirow[t]{2}{*}{ Change diet } & Reduce diet from good-quality and diverse to poor-quality monotonous diet \\
\hline & $\begin{array}{l}\text { Substitute expensive foods like meat with cheap foods which are less nutritious, e.g. meat for cabbage, cook beans } \\
\text { less often due to electricity costs, take black tea if they do not have milk }\end{array}$ \\
\hline \multirow[t]{4}{*}{ Reduce or re-allocate food intake } & Reduce the number of meals and portions \\
\hline & Give food to young children first when serving food \\
\hline & Mothers sacrifice their meals for young children \\
\hline & Mothers are the last ones to eat always \\
\hline \multirow[t]{3}{*}{ Source additional food } & $\begin{array}{l}\text { Families send younger children to pre/school so that they benefit from school food programmes. Participants } \\
\text { perceived that children eat too much when they are at home }\end{array}$ \\
\hline & $\begin{array}{l}\text { Family members go for "food for work" programmes where they would receive food parcels twice a week after } \\
\text { working half day in the fields at some institutions }\end{array}$ \\
\hline & Households receive food parcels every month from the government \\
\hline \multirow[t]{3}{*}{ Boost income to buy food } & $\begin{array}{l}\text { Households receive social or Child Support Grants every month from the government and use the money to buy } \\
\text { food }\end{array}$ \\
\hline & $\begin{array}{l}\text { Households convert their farms into timber plantations and earn income from selling timber and use the money to } \\
\text { buy food, e.g. in Richards Bay }\end{array}$ \\
\hline & $\begin{array}{l}\text { Families are involved in community projects like community gardens where they get food and sell any surplus to } \\
\text { get income which they use to buy what they need, e.g. in Dundee and Richards Bay }\end{array}$ \\
\hline
\end{tabular}


We resort to few meals and buy food that is cheaper so that we can all have a share. In these times, we will only be thinking of eating whatever we get and not what we like or prefer. We will be eating the food that we can only afford. Some families have converted their land into timber plantations where they sell timber and get money for food. Some families get food parcels from the Department of Social Development and children are given food at schools. They get rice and beans most of the time at Khayalethemba. We also have a community project in this area which is called Vukuzithathe. The name motivates people to wake up and work. We decided to fight against hunger and poverty by starting this project. We are 20 members and we grow maize, cabbage, spinach and amadumbe. The soils are fertile and we do crop rotation because the crops are seasonal. We enjoy being busy always. We grow food for our consumption and for selling but sometimes we run short of market or transport to take our produce to possible markets and our produce end up rotting. This project has helped us the members to fight against hunger and poverty since we are getting both food and income through hardworking. KwaMbonambi

We eat few meals, buy cheap food and we eat pap and cabbage or beans most of the time because meat is very expensive. We buy cheaper things like mealie meal and have black tea because we cannot afford to buy milk daily. We grow amadumbe and sweet potatoes so we can eat that throughout the day. We as mothers, we can only eat when our young children and grandchildren are full. We also cook what is enough for the meal in order to avoid throwing away food. If there are any left overs, we keep them for the next meal or day. KwaMonica

We work in the gardens at Umalusi Christian Care Centre and we get food parcels twice a week as a payment. The work for food programme is open to anyone who is in need and is willing to work. The food parcels are not enough because they are only for one person which is not enough for the whole family. For example, we only get a small quantity of mealie meal, one loaf of bread and one head of cabbage twice a week but I have a family, we are seven and the food is not enough. I have two sons but they do not want to come and work but they need food and they want me to provide for them. At Umalusi, they only give the quantity for the person who is working in the gardens. Sometimes we get social grants but the money is not enough support a large family so we go for the work for food programme and at least we get something though not enough. We eat the same meal the whole day and reduce the number of meals and only eat at night. The food parcels we get from Amalusi are not helping us out because you work and get the food that do not last you a day. We work from 8 am to 10 am but we are still hungry. Sibongile

We are only able to buy some food when we receive the grant and it's not enough to buy all the food we need. We eat what we have, pap and amahewu or pap and potatoes. We eat less food and send children to school even if they are young because they get food there at school. Young children are our priority because they cannot go for long without eating. We look for cheaper food which we can afford and eat the same meal most of the time. Social and child grants are helping to buy food although the money is not enough. We have changed the food we used to eat, we are eating pap and cabbage even on Sundays which is not proper. Food is now very expensive, we used to have rice and meat on weekends, especially on Sundays because Sundays are special days. We are struggling. Makgolokweng

\section{Discussion}

Although the information on households' diets and dietary diversity as well as sources of food may be obtained through surveys, information on why households consume food they do, why they obtain food from different sources, what determines the choice of diet and information on whether food is always available in abundance, may be limited. The present study emphasised drawing on the experiences of households in the communities, their perceptions of food security and causes of food insecurity, what they encounter when they are in the situation of food shortage, the measures they take to combat shortage of food in their households and what they feel should be done to improve food security in their communities.

\section{Diets and food diversity}

Although participants from all the focus groups seemed to be familiar with the concept of dietary diversity and a balanced diet as was hypothesised in this study, their perceptions about eating healthily were not in line with the terms as most mentioned that they eat different foods because they get tired of eating the same meal. The way they change their diets, for example, rice, pap, potatoes and samp, does not have an impact on improving their dietary diversity as they typically substitute one food for another in the same food group. Steyn et al. [39], 
Schönfeldt et al. [40] and Faber et al. [41] also reported that starchy foods, especially maize-based foods, dominate the diet of many South Africans. Fruits were rarely mentioned by the focus group participants which are also consistent with other studies in South Africa, where low intake of fruits and vegetables was reported in most poor communities [40, 41]. Most focus group participants also mentioned that they consume meat a lot and meat has also been found to be the main source of protein consumed in other parts of South Africa [42].

\section{Sources of food}

Although focus group participants mentioned that they obtain their food from different sources which included own production, purchasing, collecting from open spaces and food donations, their primary source of food was purchasing. However, in Richards Bay, own production was also an important source of food where the majority of the households were practising subsistence production and were less dependent on food purchases. Participants in Richards Bay also mentioned that own production improved their food security status as they were getting good-quality food from their fields as well as getting income from selling surpluses which they could use to buy the food which they could not produce. Baiphethi and Jacobs [16], Crush et al. [17] and Mkwambisi et al. [43] also pointed on the importance of farming in improving food security in South Africa as farm produce can substitute imported foodstuffs and this is cost-effective for poor households. In Richards Bay most people who relied on donations and purchasing every food item were regarded in their communities as being "lazy". In all communities, some households did not engage in own production because farming or gardening was regarded as indicators of poverty and it was old-fashioned. This is consistent with Aliber and Hart [15] who reported that some South African households regard obtaining food through farming as a sign of extreme poverty. Thornton [44] also noted the rejection of agriculture by the youth in South African towns of Grahamstown and Peddie as they regarded it as not part of their lifestyle, not a viable alternative to unemployment and something that is practised by the elderly.

Although agriculture has been shown to improve food security in many households, it is becoming less significant as a primary food source for many poor South African households as many are purchasing food. Focus group participants in Dundee and Harrismith also reported that their main source of food was via purchasing rather than own production. The decline in agriculture and increasing reliance on purchased food has been reported to have a negative impact on households vulnerable to food insecurity as this increases the levels of food insecurity $[1,4,7,8]$. Also, increases in food prices exacerbate food insecurity for many households [7]. Due to dependence on state social grants as a form of improving household food security in South Africa since 2001 [1], a greater proportion of the population feels that agriculture does not help significantly in their day-to-day survival. Thornton [44] calculated that participants could only save less than R100 per month in food costs when they engaged in gardening; therefore, the social grants provided the majority of poor households with the means to purchase some food. However, many participants in the FGDs of our study found the social grant insufficient for their survival and wished that the government would help with providing knowledge on agriculture and provide resources for them to fully engage into subsistence farming. For example, Kundhlande et al. [45] noted that farmers from Thaba Nchu in the Free State Province of South Africa could no longer cultivate their communal lands because they could not afford the necessary inputs as a result of removal of government support to farmers. Theft was also mentioned as one of the reasons why some households abandoned own production in many communities in the study sites as also reported by Clack [46]. The community members perceived that those members who are not growing their own food or keep own livestock and those regarded as "lazy", steal from those who are involved farming at night as many do not have tight security due to lack of income.

\section{The choice of diet}

Participants in the FGDs had different perceptions as to why they consume a particular diet. Some mentioned preference, others stated to satisfy hunger, while others had little choice but to eat whatever is available and cheap food that they can afford to buy. It was hypothesised in this study that households may not consider consuming a diverse diet due to lack of resources. Feelings of having no choice of the food one consumes have also been reported by Connell et al. [47] for children in the USA. In this case, focus group participants reported on circumstances forcing them to consume pap with potatoes, pap with amahewu or pap with cabbage, thus mostly adopting monotonous diets based on starchy staples, corroborating other studies $[40,41,48]$. The study revealed that it is beyond the reach of many households to consume a more diverse diet as many are compromising the quality of their food for cheaper and less nutritious foods that only satisfy their hunger. This is consistent with what was reported in South Africa by Brinkman et al. [49] who said most vulnerable households compromise the quality of the food by switching to cheaper and less nutritious foods that satisfy hunger in response to increasing food prices. In Canada, Chan et al. [33] reported that younger 
people would resort to cheaper foods which are reasonable in terms of cost, quality and ability to satisfy hunger although they might prefer the more expensive healthier foods such as fruits, vegetables or whole-wheat products.

As hypothesised, participants also stated that they do not consider food diversity when preparing food, but they just eat what would be available at the moment and what they could afford to buy although they know they may be missing some important nutrients in their diets. This is in line with Puoane et al. [50] who reported that household food choices in South Africa are influenced both by what is available in households' immediate environment and food prices on the market. The diet of most South Africans is rich in animal fats and low in complex carbohydrates, and it lacks fruits and vegetables because these are expensive [50]. Because of few supermarkets in the rural and peri-urban locations, households living in these areas have to travel to urban areas to buy food, which involves considerable transport cost [48]. Also, due to increases in transportation costs, food prices are forced to increase. Therefore, households resort to buying food from the local shops which are expensive and have limited variety of healthy foods, especially in rural areas, or may buy from numerous street vendors with stalls selling cheap fatty meat and fatty snacks such as "vet koek", especially in peri-urban locations [48]. Thus, most poor households access cheap but unhealthy foods. This was also mentioned in the focus groups, especially in Harrismith, where participants perceived transport costs and high food prices at local shops as some of the influencing factors to not consuming varied diets.

Market price has also been noted to have an influence on the choice and consumption of diverse foods in many households [51, 52]. Results from this study are consistent with Faber et al. [41] who reported that the diet of most South African households comprises of more energy and more processed foods, including refined grains, and foods higher in saturated fat, sugar and salt which are cheaper to buy. The cost of electricity was also mentioned by the focus group participants as a contributing factor to food insecurity in their households as they perceived the cost to be too high, taking a huge portion of their income as was reported by Abdu-Raheem and Worth [53] in South Africa. Therefore, total household income is a major determinant of household food security in South Africa as this directly affects the type of food a household consumes.

\section{Food abundance, food insecurity and coping strategies}

Participants stated that food is readily available at the markets throughout the year, but the problem of limited access to the food was emphasised, as hypothesised in this study. Because these focus groups were carried in the rural and peri-urban locations (except one in Dundee), many agreed that they had limited access to affordable food as they face higher prices for food, while some had limited financial access. These areas are characterised by high levels of poverty and unemployment; therefore, household income and wealth status determine the level of household food security through the ability of the household to access food [11]. This corresponds closely to what has been documented that South Africa is food secure at national level $[10,54]$, but large numbers of households within the country are food insecure as about $20 \%$ of South African households are estimated to have inadequate or severely inadequate access to food [55].

Focus group participants, especially in Dundee and Harrismith, articulated that barriers to food access are mostly low income, poor climatic conditions, water shortages, poverty, unemployment, no access to land, rising food prices and lack of resources to practise farming. This was hypothesised in this study and is in line with reports by the Human Science Research Council (HSRC) [56] who mentioned that widespread chronic poverty and unemployment are the main causes of food insecurity in South Africa. Chopra et al. [57] also reported that household food insecurity was consistent with income, employment status and food expenditure in Eastern Cape, Northern Cape and Limpopo Provinces in South Africa. However, Shackleton et al. [4] and Musemwa et al. [8] noted that the high food insecurity levels could be due to a decline in smallholder agriculture as the majority of South Africans access their food through purchasing from the markets. Households in Richards Bay who were engaging in own production perceived that they were food secure unlike in Dundee and Harrismith who relied mostly on purchasing. Water shortages in many communities have also been implicated as driving forces preventing most households from growing crops on their homesteads, thereby increasing food insecurity [58]. FAO [59] noted that availability and access to land and water resources are of the greatest importance in improving food security as well as reducing poverty globally. Cook et al. [60] and Kemp-Benedict et al. [61] reported that food security along the agricultural basins located in the Limpopo Province is strongly determined by water availability and use. Therefore, availability of water can increase agricultural production which in turn can improve food security and reduce poverty, as was perceived by the focus group participants.

Increases in food prices cause the most vulnerable households to reduce dietary diversity $[7,49]$. It becomes very difficult for most households, especially low-income households, to consume a more diverse diet with a diverse range of foods as the majority of South African households are struggling to sustain a decent income 
[2] and many cannot afford to purchase fruits and vegetables. Therefore, households reduce the consumption of more expensive food items as well as dietary diversity, portions and frequency of meals $[49,62]$. As was hypothesised, reducing the quality, quantity and frequency of meals consumed per day was mentioned by the focus group participants as one of the ways they cope with food shortages. This supports findings by Oldewage-Theron et al. [62] and Battersby and McLachlan [63] reporting that during periods of food shortages, households decrease the variety of foods eaten, reduce portion sizes and may eat cheaper fast foods.

Some households in these communities prioritise the diets of small children as they buffer the youngest children from declines in food intake and some mothers prioritise their children's food consumption over their own. Thus, households in the study sites cope with declines in food availability without sacrificing calorie adequacy for vulnerable members which are young children in this case. Many perceived that the food parcels, the Child Support Grant and school feeding programmes are also part of their coping strategies as they get food from the government, use the grant money to buy food as well as send children to school where they receive food. In South Africa, the Child Support Grant and school food programmes have been attributed to lower levels of malnutrition [2].

The most vulnerable members in the communities were identified as mostly female-headed households who are taking care of children, orphaned children and grandchildren, those families with unemployed members and those with low cash-flow and only survive on social grants as well as those who are regarded as "lazy". This was also noted by FAO [64] that the rural and urban poor, the landless and female-headed households are the major groups that are affected by food price increases. Women, especially of reproductive age, and young children were also noted as the most vulnerable groups in a study by Chakona [11]. Jacobs [65] and Rudolph et al. [66] noted that low-income households are more likely to suffer from food shortages because food expenditure makes up a large share of their spending, thereby causing them to be more vulnerable to the impacts of rising food prices. Low income, low asset ownership and unemployment also increased the risk of food insecurity in households in the informal settlements of Johannesburg in South Africa [66].

\section{Community perceptions on improving food security}

Although households may implement any of several coping strategies, participants perceived that there is room to improve food security in their communities with the help and support from the government and also working together as community members. They argued that the government should provide them with inputs and agricultural knowledge and also provide services (such as land and water) which can help them achieve farming as they agreed that farming can improve food security. This is in line with what was reported by Kundhlande et al. [45] where farmers from Thaba Nchu in the Free State abandoned agriculture due to lack of resources and no government support. In Dundee and Harrismith, where water scarcity was an issue, they wished the government could provide taps so that they can establish home or community gardening projects. Community gardening projects have been noted to provide families with fresh vegetables, reduce food insecurity, improve dietary intake and strengthen social relationships as community members provide advice and support to overcome challenges [67]. Home gardens also increase food availability and access as well as promoting a nutritious diet as these may directly contribute to household food security. Seeking employment was also perceived by most participants as another way to improve food security as this would increase their income status.

\section{Conclusion}

The focus group participants were knowledgeable about eating healthily. Their perceptions about difficulties in access to diverse food and consuming healthy diets reflect that food might be abundant but with limited access to many households. The perceptions provided insights into the pressing issues of food security in small towns as participants touched on the issues of inadequate access to food, coping strategies and their ideas on improving food security in their communities. The majority of households are experiencing food insecurity, and female-headed households, unemployed and orphaned children are most vulnerable. Focus group participants from all communities highlighted the complexity of the food system in their communities which relies on own production, collecting from open spaces, donations and to a larger extent purchase, in the context of unemployment, low income, water and land shortages as well as theft. Although social grants and school food programmes are helping to alleviate food insecurity, participants still feel it is not enough and are facing difficult challenges with food insecurity. The results provide a significant contribution from a needs assessment perspective from the communities, identify "hidden" constrains in household food access and provide effective future solutions for improving food security in the communities. Government should assist with capacity building, employment creation and providing resources (especially, land and water) for them to practise agriculture which they all agreed can be used to improve food security. 


\section{Authors' contributions}

GC initiated, analysed and wrote this manuscript under the supervision of CS who guided the entire write-up of the manuscript. Both authors read and approved the final manuscript.

\section{Acknowledgements}

We wish to thank VW Foundation for the financial support to GC. We also wish to thank the participants from Richards Bay, Dundee and Harrismith for willingly participating in this research.

\section{Competing interests}

The authors declare that they have no competing interests.

\section{Availability of data and materials}

The data sets used and/or analysed during the current study are available from the corresponding author on reasonable request.

\section{Consent for publication}

All the authors and the institution concerned have approved their consent for the publication of this work.

\section{Declaration}

Both GC and CS hereby declare that with the exception of references consulted which have been duly cited and acknowledged, the work presented is original.

\section{Ethics approval and consent to participate}

Ethics approval was granted by the Rhodes University Ethical Standards Committee with Permit Number RU-HSD-14-08-0012. Informed consent to carry out this research was obtained from each participant in the focus groups before the interviews.

\section{Publisher's Note}

Springer Nature remains neutral with regard to jurisdictional claims in published maps and institutional affiliations.

Received: 7 September 2017 Accepted: 24 November 2017

Published online: 02 December 2017

\section{References}

1. Altman M, Hart T, Jacobs P. Household food security status in South Africa. Agrekon. 2009;48(4):345-61.

2. Labadarios D, Mchiza ZJL, Steyn NP, Gerike G, Mounder EMW, Davids YD, Parker W. Food security in South Africa: a review of national surveys. Bull World Health Organ. 2011:89(12):891-9.

3. Hebinck PGM, Lent PC, editors. Livelihoods and landscapes: the people of Guquka and Koloni and their resources, vol. 9. Brill: Leiden; 2007.

4. Shackleton R, Shackleton C, Shackleton S, Gambiza J. Deagrarianisation and forest revegetation in a biodiversity hotspot on the Wild Coast, South Africa. PloS ONE. 2013;8(10):e76939.

5. Statistics South Africa (Stats SA). Consumer Price index, March 2016. Pretoria: Statistics South Africa; 2016.

6. World Food Programme (WFP). Global Food Security Update: tracking food security trends in vulnerable countries (southern Africa). Issue 21 March 2016. Rome: United Nations World Food Programme; 2016.

7. Crush J, Frayne B. Urban food insecurity and the new international food security agenda. Dev S Afr. 2011;28(4):527-44.

8. Musemwa L, Muchenje V, Mushunje A, Aghdasi F, Zhou L. Household food insecurity in the poorest province of South Africa: level, causes and coping strategies. Food Secur. 2015;7(3):647-55.

9. Food and Agriculture Organisation (FAO). The State of Food and Agriculture 1996. Rome: Food and Agriculture Organisation of the United Nations; 1996.

10. National Department of Agriculture (NDA). Integrated food security strategy. Pretoria: NDA; 2002.
11. Chakona G, Shackleton C. Minimum dietary diversity scores for women indicate micronutrient adequacy and food insecurity status in South African Towns. Nutrients. 2017;9(8):812.

12. Hendriks SL, Kirsten J, Vink N. The effect of institutions and policies on food security and rural development in South Africa. J Dev Perspect. 2006;2(1):86-102.

13. Shisanya SO, Hendriks SL. The contribution of community gardens to food security in the Maphephetheni uplands, determined by the Household Food Insecurity Access Scale. Dev S Afr. 2011;28(4):509-26.

14. Hendriks S. Food security in South Africa: status quo and policy imperatives. Agrekon. 2014;53(2):1-24.

15. Aliber M, Hart TG. Should subsistence agriculture be supported as a strategy to address rural food insecurity? Agrekon. 2009;48(4):434-58.

16. Baiphethi MN, Jacobs PT. The contribution of subsistence farming to food security in South Africa. Agrekon. 2009;48(4):459-82.

17. Crush J, Hovorka A, Tevera D. Food security in Southern African cities: the place of urban agriculture. Prog Dev Stud. 2011;11(4):285-305.

18. Shackleton SE, Campbell B, Lotz-Sisitka H, Shackleton CM. Links between the local trade in natural products, livelihoods and poverty alleviation in a semi-arid region of South Africa. World Dev. 2008;36:505-26.

19. Davenport NA, Gambiza J, Shackleton CM. Use and users of municipal commonage around three small towns in the Eastern Cape, South Africa. J Environ Manag. 2011;92(6):1449-60.

20. Davenport NA, Shackleton CM, Gambiza J. The direct use value of municipal commonage goods and services to urban households in the Eastern Cape, South Africa. Land Use Policy. 2012;29(3):548-57.

21. Shackleton CM, Shackleton SE, Gambiza J, Nel E, Rowntree $K$, Urquhart $P$, Fabricus C, Ainslie A. Livelihoods and vulnerability in the arid and semiarid lands of southern Africa: exploring the links between ecosystem services and poverty alleviation. New York: Nova Publishers; 2010.

22. Arnold M, Powell B, Shanley P, Sunderland TCH. Forests, biodiversity and food security. Int Forest Rev. 2011;13(3):259-64.

23. Bharucha Z, Pretty J. The roles and values of wild foods in agricultural systems. Philos Trans R Soc Lond B Biol Sci. 2010;365(1554):2913-26.

24. Legwaila GM, Mojeremane W, Madisa ME, Mmolotsi RM, Rampart M. Potential of traditional food plants in rural household food security in Botswana. J Hortic For. 2011;3(6):171-7.

25. Mavengahama S, McLachlan M, De Clercq W. The role of wild vegetable species in household food security in maize based subsistence cropping systems. Food Secur. 2013;5(2):227-33.

26. Melgar-Quinonez $H$, Hackett M. Measuring household food security: the global experience. Rev Nutr. 2008;21:27s-37s.

27. Food and Agriculture Organisation (FAO). The state of food insecurity in the world: monitoring progress towards the World Food Summit and Millennium Development Goals. Rome; 2004.

28. Food and Agriculture Organisation (FAO). Report on use of the Household Food Insecurity Access Scale and Household Dietary Diversity Score in two survey rounds in Manica and Sofala Provinces, Mozambique, 2006-2007. FAO food security project. GCP/MOZ/079/BEL; 2008.

29. Hoddinott J, Yohannes Y. Dietary diversity as a household food security indicator. Washington, DC: FANTA Project, Academy for Educational Development; 2002.

30. Wolfe WS, Frongillo EA. Building household food security measurement tools from the ground up. Food Nutr Bull. 2001;22(1):5-12.

31. Hamelin AM, Habicht JP, Beaudry M. Food insecurity: consequences for the household and broader social implications. J Nutr. 1999:129(2):525S-8S

32. Hamelin AM, Beaudry M, Habicht JP. Characterization of household food insecurity in Quebec: food and feelings. Soc Sci Med. 2002;54(1):119-32.

33. Chan HM, Fediuk K, Hamilton S, Rostas L, Caughey A, Kuhnlein H, Egeland G, Loring E. Food security in Nunavut, Canada: barriers and recommendations. Int J Circumpolar Health. 2006;65(5):416-31.

34. Krueger RA. Focus groups. A practical guide for applied research. 2 nd ed. Thousand Oaks: Sage; 1994.

35. Fossey E, Harvey C, McDermott F, Davidson L. Understanding and evaluating qualitative research. Aust N Z J Psychiatry. 2002;36(6):717-32.

36. Vaismoradi M, Turunen $\mathrm{H}$, Bondas $\mathrm{T}$. Content analysis and thematic analysis: implications for conducting a qualitative descriptive study. Nurs Health Sci. 2013;15(3):398-405. 
37. Raibee F. Focus-group interview and data analysis. Proc Nutr Soc. 2004;63:655-60.

38. Saldaña J. The coding manual for qualitative researchers. London: Sage Publications; 2009.

39. Steyn NP, Nel JH, Nantel G, Kennedy G, Labadarios D. Food variety and dietary diversity scores in children: are they good indicators of dietary adequacy? Public Health Nutr. 2006;9(05):644-50.

40. Schönfeldt $\mathrm{HC}$, Gibson N, Vermeulen $\mathrm{H}$. The possible impact of inflation on nutritionally vulnerable households in a developing country using South Africa as a case study. Nutr Bull. 2010;35(3):254-67.

41. Faber M, Witten C, Drimie S. Community-based agricultural interventions in the context of food and nutrition security in South Africa. S Afr J Clin Nutr. 2011;24(1):21-30.

42. Acham H, Oldewage-Theron WH, Egal AA. Dietary diversity, micronutrient intake and their variation among black women in informal settlements in South Africa: a cross-sectional study. Int J Nutr Metab. 2012;4(2):24-39.

43. Mkwambisi DD, Fraser ED, Dougill AJ. Urban agriculture and poverty reduction: evaluating how food production in cities contributes to food security, employment and income in Malawi. J Int Dev. 2011;23(2):181-203.

44. Thornton A. Beyond the metropolis: small town case studies of urban and peri-urban agriculture in South Africa. Urban Forum. 2008;19(3):243-62.

45. Kundhlande G, Groenewald DG, Baiphethi MN, Viljoen MF, Botha JJ, Van Rensburg LD, Anderson JJ. Socio-economic study of water conservation techniques in semi-arid areas. Report No. 1267/1/04, Water Research Commission. Pretoria; 2004.

46. Clack W. The extent of stock theft in South Africa. CRIMSA J Acta Criminol. 2013;26(2):77-91.

47. Connell CL, Lofton KL, Yadrick K, Rehner TA. Children's experiences of food insecurity can assist in understanding its effect on their well-being. J Nutr. 2005;135(7):1683-90.

48. Ncube K, Shackleton CM, Swallow BM, Dassanayake W. Impacts of HIV/ AIDS on food consumption and wild food use in rural South Africa. Food Secur. 2016;8(6):1135-51.

49. Brinkman HJ, de Pee S, Sanogo I, Subran L, Bloem MW. High food prices and the global financial crisis have reduced access to nutritious food and worsened nutritional status and health. J Nutr. 2010;140(1):153S-61S.

50. Puoane T, Fourie JM, Shapiro M, Rosling L, Tshaka NC, Oelefse A. Big is beautiful —an exploration with urban black community health workers in a South African township. S Afr J Clin Nutr. 2005;18(1):6-15.

51. Monsivais P, Drewnowski A. The rising cost of low-energy-density foods. J Am Diet Assoc. 2007;107(12):2071-6.

52. Hussain A, Zulfiqar F, Saboor A. Changing food patterns across the seasons in rural Pakistan: analysis of food variety, dietary diversity and calorie intake. Ecol Food Nutr. 2014;53(2):119-41.
53. Abdu-Raheem KA, Worth SH. Household food security in South Africa: evaluating extension's paradigms relative to the current food security and development goals. S Afr J Agric Ext. 2011;39(2):91-103.

54. Human Sciences Research Council (HSRC). Food security in South Africa: key policy issues for the medium term. Pretoria: Position paper: Integrated Rural and Regional Development; 2004

55. Statistics South Africa (Stats SA). Poverty trends in South Africa. An examination of absolute poverty between 2006 and 2011. Report No. 03-10-06. Pretoria: Statistics South Africa; 2014.

56. Human Sciences Research Council (HSRC). Achieving food security in South Africa: characteristics, stressors and recommendations to 2019. Report to the office of the Presidency (June). Pretoria; 2007.

57. Chopra M, Daviaud E, Pattinson R, Fonn S, Lawn JE. Saving the lives of South Africa's mothers, babies, and children: can the health system deliver? Lancet. 2009;374(9692):835-46.

58. Stimie CM, Kruger E, De Lange M, Crosby CT. Agricultural water use in homestead gardening systems. Volume 2: Main Report. Report No. TT430/09. Pretoria: Water Research Commission; 2010.

59. Food and Agriculture Organisation (FAO). Guidelines for measuring household and individual dietary diversity. Rome: Food and Agriculture Organisation of the United Nations; 2011.

60. Cook S, Fisher M, Tiemann T, Vidal A. Water, food and poverty: global- and basin-scale analysis. Water Int. 2011;36(1):1-16.

61. Kemp-Benedict E, Cook S, Allen SL, Vosti S, Lemoalle J, Giordano M, Ward J, Kaczan D. Connections between poverty, water and agriculture: evidence from 10 river basins. Water Int. 2011;36:125-40.

62. Oldewage-Theron WH, Dicks EG, Napier CE. Poverty, household food insecurity and nutrition: coping strategies in an informal settlement in the Vaal Triangle, South Africa. Public Health. 2006;120(9):795-804.

63. Battersby J, McLachlan M. Urban food insecurity: a neglected public health challenge. S Afr Med J. 2013;103(10):716-7.

64. Food and Agriculture Organisation (FAO). The state of food insecurity in the world: economic crises-impacts and lessons. Rome: Food and Agriculture Organisation (FAO); 2009.

65. Jacobs PT. The status of household food security targets in South Africa. Agrekon. 2009;48(4):410-33.

66. Rudolph M, Kroll F, Ruysenaar S, Dlamini T. The state of food insecurity in Johannesburg. Urban Food Security Series No. 12. Queen's University and AFSUN. Kingston and Cape Town; 2012.

67. Carney PA, Hamada JL, Rdesinski R, Sprager L, Nichols KR, Liu BY, Pelayo J, Sanchez MA, Shannon J. Impact of a community gardening project on vegetable intake, food security and family relationships: a community-based participatory research study. J Community Health. 2012;37(4):874-81.

\section{Submit your next manuscript to BioMed Central and we will help you at every step:}

- We accept pre-submission inquiries

- Our selector tool helps you to find the most relevant journal

- We provide round the clock customer support

- Convenient online submission

- Thorough peer review

- Inclusion in PubMed and all major indexing services

- Maximum visibility for your research

Submit your manuscript at www.biomedcentral.com/submit
(OioMed Central 